International Review of Research in Open and Distributed Learning Volume 20, Number 2

April - 2019

\title{
Online Teacher and On-site Facilitator Perceptions of Parental Engagement at a Supplemental Virtual High School
}

Jered Borup ${ }^{1}$, Chawanna Chambers ${ }^{2}$, and Rebecca Srimson ${ }^{3}$

1,2George Mason University, ${ }^{3}$ Michigan Virtual Learning Research Institute

\begin{abstract}
Just as they have in face-to-face courses, parents will likely play an important role in lowering online student attrition rates, but more research is needed that identifies ways parents can engage in their students' online learning. In this research we surveyed and interviewed 12 online teachers and 12 on-site facilitators regarding their experiences and perceptions of parental engagement. Guided by the Adolescent Community of Engagement framework, our analysis found that teachers and facilitators valued parents' engagement when parents advised students on course enrollments, nurtured relationships and communication with and between students, monitored student progress, motivated students to engage in learning activities, organized and managed students' learning time at home, and instructed students regarding study strategies and course content when able. Teachers and facilitators also identified obstacles that parents faced when attempting to engage in their children's online learning as well as obstacles that teachers and facilitators encountered when they attempted to support parents.
\end{abstract}

Keywords: parental engagement, online learning, student engagement, virtual schooling, online teachers, on-site facilitators 


\section{Introduction}

K-12 students are increasingly enrolling in online courses. Most enrollments occur in the upper grades and most of those enrollments are used to supplement traditional coursework (Evergreen Education Group, 2017). It is also becoming increasingly clear that K-12 online courses have significantly higher attrition rates than those found in face-to-face courses (Freidhoff, 2017). Roblyer, Freeman, Stabler, and Schmeidmiller (2007) explained that students' ability to complete an online course has less to do with their ability to learn course content and "appears to depend more on motivation, self-direction, or the ability to take responsibility for individual learning” (p. 11).

Online programs commonly rely on parents to provide the support that is difficult or impossible for their teachers to provide at a distance. However, parental engagement in online courses can vary greatly, and the quality and quantity of parental support that students receive is a major concern for online teachers (Larkin, Brantley-Dias, \& Lokey-Vega, 2015). As a result, some online programs require local schools to provide students with an on-site facilitator who works with students face-to-face (Borup, 2018). Although an engaged on-site facilitator can alleviate some of the burden placed on parents, a facilitator is not meant to eliminate parental involvement. Little research has attempted to identify how parents should engage in their students' online courses, and the research that does exist tends to focus on full-time programs where parents assume a high level of responsibility because students take all or most of their courses from home (Borup, 2016; Hasler Waters \&Leong, 2014). As a result, little is known regarding how online teachers, onsitefacilitators, and parents in supplemental online programs share support responsibilities. Weaddressed this need by interviewing successful online teachers and on-site facilitators regarding their perceptions and experiences related to parental engagement and the obstacles they and parents encountered. Specifically, our research addressed the following questions:

1. Based on online teacher and on-site facilitator perceptions and experiences, what are parents' responsibilities when their students are enrolled in a supplemental online course with on-site facilitator support?

2. Based on online teacher and on-site facilitator perceptions and experiences, what are the obstacles that parents face when attempting to fulfill their responsibilities in online courses?

\section{Literature Review}

In this section we will first review parental engagement frameworks. Next, we will review the literature examining the levels and impact of parental engagement on student performance.

\section{Parental Engagement Framework}

Researchers examining parental engagement in online courses have sought guidance from more established frameworks created in face-to-face learning environments, mainly Epstein's (1995) and Hoover-Dempsey and Sandler's (1995, 2005) frameworks of parental engagement (see Black, 2009; Hasler Waters, 2012; Liu, Black, Algina, Cavanaugh, \&Daswon, 2010). These frameworks proved helpful in collecting and analyzing data, but ultimately were inadequate in describing parental engagement in online courses and 
generalizations across online and face-to-face courses should be avoided. As a result, Borup, West, Graham, and Davies (2014) used research on parental engagement in online settings to critically examine the parental engagement frameworks established in traditional environments and to identify several types of parental engagement as described in their Adolescent Community of Engagement (ACE) framework. Borup and his colleagues (Borup, 2016; Borup, Stevens, \& Hasler Waters, 2015) then conducted case studies examining parent engagement at a full-time online charter high school that helped further refine the framework. The following summarizes the types of parent engagement identified in Borup et al.'s (2014) original article and two subsequent case studies (Borup, 2016; Borup et al., 2015):

1. Organizing and managing: Helping students organize their home learning environments and manage their time.

2. Instructing: Answering students' content-related questions when able, helping them develop study/learning skills, providing preliminary feedback on their work, and assisting when technological issues arise.

3. Facilitating interactions: Supporting students' attempts to interact with the content and others (i.e., online teacher, on-site facilitator, and peers) by:

a) Advising and mentoring students in their enrollment decisions and in setting long-term educational goals.

b) Nurturing caring relationships and working to open lines of communication with the online teacher and on-site facilitator.

c) Monitoring student progress and performance.

d) Motivating students to more fully engage in learning activities and thereby progress in the course.

The authors of the ACE framework acknowledged "that there are several types of learning models, each requiring different levels of teacher, parent, and peer engagement" and that "differing learner models will also place varying emphasis on parent engagement" (Borup et al., 2014, p. 23). The case studies conducted in a full-time online school have proven insightful, but it is also important to examine parental engagement in supplemental online programs where students also receive support from an online teacher and on-site facilitator.

While the ACE framework focused on the types of parental engagement, Hoover-Dempsey and Sandler's $(1995,2005)$ framework of parental engagement provided insights into why parents choose to be involved in their students' learning. They identified three primary factors that contribute to parental engagement behaviors: (1) parents' motivational beliefs; (2) the types of invitations parents receive from their student and others; and (3) parents' perceived ability, availability, and energy to help (Hoover-Dempsey \& Sandler, 1995, 2005). While the three factors outlined above were developed in face-to-face environments, they appear generic enough to also apply to online environments, although they have yet to be applied in those settings. However, it is important to note that parents' motivational beliefs and their abilities to actually 
engage in their students' online learning are likely different when they are facilitating online courses than they would be in face-to-face settings, especially when parents have limited understanding and experiences with online courses. As a result, it is important to understand why and how parents choose to be involved in their students' learning within the context of online courses.

\section{Parental Engagement: Levels and Impact}

Researchers have found a large variance in the levels of parental engagement in their students' online courses. Litke's (1998) case study was the first to document this phenomenon when he categorized three types of parents:

- Absentee: Parents who were largely uninvolved in their students' learning.

- Supporters: Parents who regularly asked their students and occasionally the teachers regarding student progress, then increased their involvement when difficulties were identified.

- Participatory: Parents who maintained a high level of engagement throughout the semester by closely checking grades, supervising learning activities, tutoring frequently, and actually working side-by-side with their students.

More recently, Borup, Graham, and Davies (2013) surveyed 79 parents at a full-time online charter high school regarding the average number of minutes they spent each week interacting with each course instructor and student regarding the online course work. On average, these parents reported spending an average of 86 minutes ( $\mathrm{SD}=74.3$ ) interacting with their students and 9.1 minutes ( $\mathrm{SD}=14.2$ ) interacting with the course teacher-both with high standard deviations from the mean (Borup et al., 2013).

While schools commonly have policies that require teacher-parent communication, the policies tend to emphasize contacting parents when students' performance had decreased, rather than maintaining a high level of communication throughout the semester (Cavanaugh et al., 2009). Research has also found that both parents and teachers expect the other to do more to support student learning (Hasler Waters \& Leong, 2014). As a result, online programs should better establish parental engagement expectations and provide parents with information regarding the types of support required.

Whereas qualitative research has indicated that parents have a positive impact on student engagement, findings from quantitative correlational research have been mixed. More specifically, Black (2009) and Borup et al. (2013) both failed to consistently find significant positive correlations between levels of parental engagement and several online course outcomes. In fact, in some cases levels of parental engagement were actually negatively correlated with course outcomes, although these negative correlations were not statistically significant. These researchers warned against a simplistic conclusion that parents do not meaningfully impact students' learning outcomes in online courses, because the lack of significant correlations could have been the result of other factors. For instance, Borup et al. (2013) stated, "If a large portion of parental interaction occurred in reaction to poor student performance, the correlation that results from examining a large group of students could mask the true benefit of parental involvement on individual studentlearning" (p. 52). Research in face-to-face settings has found that not all types of parental engagement equally impacted learning outcomes (McNeal, 2012; Wilder, 2014). McNeal (2012) and Wilder 
(2014) recommend examining specific types of parental engagement rather than total parental engagement. An obstacle to following McNeal's recommendation is that little research has worked to identify specific types of parental engagement in online courses-especially in supplemental programs that provide on-site facilitator support.

\section{Methods}

\section{Research Setting}

Michigan Virtual (MV), a large state-run virtual school, was selected as the setting for this research. During the 2015-2016 academic year MV enrolled 8,710 students who accounted for 19,098 individual course enrollments (Freidhoff, 2017). The large majority of MV students enrolled in online courses as a way to supplement their face-to-face courses. Section 21f of Michigan Public Act No. 60 (2013) required the local brick-and-mortar school to provide students enrolled in online courses with an on-site facilitator, referred to as a "mentor," who must be "available for assistance to the pupil" and "monitor the pupil's progress in the course" (p. 5-O-A-1). Online teachers were charged with "determining appropriate instructional methods for each pupil, diagnosing learning needs, assessing pupil learning, prescribing intervention strategies, reporting outcomes, and evaluating the effects of instruction and support strategies" (Michigan Department of Education, 2014, 5-O-D-2). MV also provides a parent guide that explains the roles of the online teacher and on-site facilitator and advises parents to create a study space for the student, prepare for technological issues, review the syllabus with the student, define expectations, set incentives and punishments, help the student establish a learning routine, and monitor progress weekly in the learning management system (Michigan Virtual, 2017).

\section{Participants and Data Collection}

Using MV student pass rate data from the previous academic period, we identified schools with above average student pass rates ( $80 \%$ or higher) and then sampled 12 schools across the state (four urban, four suburban, four town, and four rural). The on-site facilitator with the highest student load at each of the 12 schools was then sampled for participation. All of the participating on-site facilitators were full-time employees of the local school districts with student loads ranging between 15 and 300, with an average of 95 students ( $\mathrm{SD}=79.6$ ). Seven focused only on their facilitator responsibilities, and the other five divided their time facilitating online students' learning with other teaching or administrative responsibilities. It is also important to note that 11 of the facilitators required the majority of their online students to attend a daily lab. The only exception was a vice principal who required students to only attend a weekly lab but commonly met with students in his office during the week.

On-site facilitators provided names of three online teachers who they believed were particularly effective in working with students. We then sampled 12 online teachers (giving preference to the teachers with multiple recommendations and sampling online teachers across the content areas taught) who then completed a survey and participated in two 50-60 minute interviews similar to those given to on-site facilitators. Of the participating online teachers, only nine taught online (eight full-time and one part-time). 
All online teacher and on-site facilitator participants completed a survey that asked general demographic and workload information before asking participants to list the responsibilities assumed by the online teacher, on-site facilitator, and parents. Participants then ranked the provided responsibilities in order of importance. Each participant then participated in two 50-60 minute interviews for a total of 48 interviews. The interviews allowed participants to expand on their survey responses and share experiences related online teacher, on-site facilitator, and parent responsibilities.

\section{Data Analysis}

The interview transcripts were sent back to the participants who checked them for accuracy. The first interview analysis focused on online teacher and on-site facilitator responsibilities. The results of that analysis can be found at (Borup \& Stimson, 2019). The analysis for this article focused specifically on parental responsibilities. More specifically, before a statement was coded, it was compared to all previous coded statements, a practice Glaser (1965) called the "basic, defining rule for the constant comparative method" (p. 439). Similar categories were then grouped together. The groupings were guided by the elements of parental engagement identified in the ACE framework. However, we were careful not to limit the groupings and were also attentive to categories not previously identified by the framework. One researcher coded the online teacher interviews, and another researcher coded the on-site facilitator interviews. The research team met frequently throughout the analysis to review the coded statements and discuss the category groupings. When there were disagreements, we discussed them until the issues were resolved and everyone was in agreement.

\section{Findings}

When referring to a specific participant, we changed the name and placed either $(F)$ or $(T)$ next to the name to indicate if that person were a facilitator or a teacher. Facilitators and teachers found that the actual levels of engagement could vary greatly across parents. Rick (T) explained that "parents are either completely all in" or "you never even hear from that parent the whole semester." Although on-site facilitators and online teachers acknowledged that "some students are incredibly motivated" and "don't really need their parents to cheerlead or support or do anything," they also agreed that parents were "incredibly helpful" for the large majority of their students and that many of their students would "end up failing the course" if their parents were not involved. In general, on-site facilitators and online teachers found that parental engagement was not as high as they believed it should be and "wish[ed] that parents would be more involved." However, Lisa (F) found that while parental "involvement is minimal," parents usually got involved when there was an immediate need.

Facilitators and teachers believed that when a facilitator was highly involved and consistently met with students, the need for parental engagement was lower than if facilitators only met with the student sporadically. In fact, facilitators tended to agree that when online students attended a daily lab, parents' needed level of engagement was similar to when students were learning in a traditional face-to-face course. Inversely, Devon (T) explained that when students are learning primarily from home with little face-to-face 
contact with their facilitator, the parents "are the ones who are doing the things that [the facilitator] would normally do."

On their surveys, teachers and facilitators listed specific parental responsibilities that we then coded and categorized (see Table 1). In their interviews, teachers and facilitators elaborated on their survey responses and shared potential obstacles that parents encountered when attempting to fulfill their responsibilities. In doing so, teachers and facilitators reinforced the themes that were identified in the survey responses with some exceptions. For instance, advising students on their online course enrollment was listed as a parental responsibility by only one survey respondent but became an important theme in the interview analysis.

Table 1

Survey Analysis Results of the Listed Parent Responsibilities

\begin{tabular}{|c|c|c|c|c|c|}
\hline Responsibility & $\begin{array}{l}\text { Facilitators } \\
(\mathbf{n}=)\end{array}$ & $\begin{array}{l}\text { Teachers } \\
(\mathbf{n}=)\end{array}$ & $\begin{array}{l}\text { Avg. } \\
\text { Rank }\end{array}$ & SD & Example quote \\
\hline Motivating & 9 & 8 & 2.14 & 0.95 & $\begin{array}{l}\text { "Motivating student if they fall } \\
\text { behind." }\end{array}$ \\
\hline Monitoring & 11 & 5 & 1.72 & 0.77 & $\begin{array}{l}\text { "Keep track of their student's progress } \\
\text { in their course by looking at their } \\
\text { grades." }\end{array}$ \\
\hline $\begin{array}{l}\text { Nurturing } \\
\text { Communication }\end{array}$ & 7 & 8 & 2.20 & 1.01 & $\begin{array}{l}\text { "Maintain communication with student } \\
\text { and [facilitator] regarding their child's } \\
\text { online course." }\end{array}$ \\
\hline Managing & 2 & 3 & 1.35 & 0.93 & $\begin{array}{l}\text { "Keep the students on pace to complete } \\
\text { the course." }\end{array}$ \\
\hline Instructing & 2 & 3 & 1.90 & 0.89 & $\begin{array}{l}\text { "Provide support when appropriate, } \\
\text { tutoring." }\end{array}$ \\
\hline Organizing & 3 & 1 & 1.38 & 0.75 & $\begin{array}{l}\text { "Provide a space in the home that is } \\
\text { conducive for learning while working } \\
\text { on the computer." }\end{array}$ \\
\hline Modeling & 1 & 1 & 4 & 1.41 & "Be role model for their child." \\
\hline Advising & 0 & 1 & 1 & $\mathrm{Na}$ & $\begin{array}{l}\text { "Be informed of their student's } \\
\text { enrollment." }\end{array}$ \\
\hline
\end{tabular}

\section{Advising}

Teachers and facilitators believed that parents could be an important partner when advising students regarding online course enrollments. In practice, however, teachers and facilitators believed that parents "need to be so much more involved in all of thekids' course selections than they are." In fact, online teachers commonly shared experiences of reaching out to parents who were unaware that their student was even enrolled in an online course. Angela (T) stated that it was a significant problem and that "a good portion of our parents don't even know their student is taking an online class." Rick (T) believed that parental lack of awareness regarding their students' online course enrollments was one of the "biggest recurring themes" and caused "a frustrating situation" for both parents and teachers.

Even when parents advised their students regarding course enrollments, they often lacked the necessary understanding of online learning to provide recommendations that were in students' best interest. For instance, Caitlyn (F) found that "A lot of times, parents have blinders" and "only see what they want to see" 
in regards to their students' capabilities, so they end up "pushing or allowing" their students to enroll in an online course regardless of the student's abilities or readiness. Kay (F) stated that parents' misconceptions about online courses are to be expected because parents have "never been in one before." Facilitators and teachers also found that many parents falsely assumed that "online learning is just easier than face-to-face [courses]" and are "surprised at how difficult the work may be and how much time a student will have to spend trying to learn it."

In an attempt to overcome these misconceptions, online teachers provided orientation materials that facilitators would then supplement before sending them home for students and parents to sign and return. Caitlyn ( $F$ ) found that this resulted in "a really long letter because there's so much information," and Kay would "always wonder how many parents read them [before signing]." Facilitators found that it was "really hard" to overcome parents' misconceptions and some, such as Tanner (F), wished to have a "parent night" specifically for online courses.

\section{Nurturing Relationships and Communication}

Facilitators and teachers believed that parents "nurturing and caring" for their students was foundational to their ability to positively impact their students' learning because they would have the "student's ear." Teachers and facilitators also recognized that the inverse could be true, and "some students feel that, 'Hey, if my mom and dad doesn't care if I'm successful, why should I care?'”

Teachers added that parents should respond to teacher inquiries as well as proactively contact them when the need arises. Teachers found that only a few parents actually contacted them directly. Kandice (T) concluded that "a lot of parents don't know that I'm somebody that they can reach out to." Simply contacting parents proved challenging for teachers because they were dependent on local schools to provide them with accurate parental contact information at the time of registration - a responsibility that schools commonly failed to fulfill. When teachers did not have accurate contact information for parents, they worked with the local facilitator to relay messages to the parent. However, even facilitators found that their parent communication was "a mixed bag." Kay (F) stated, "I have some [parents] who are involved and some that I never hear from. So I always wonder, 'Are you getting my emails? Are you there? Is there anybody on the other end?"”

\section{Monitoring Student Progress}

Once students were enrolled in an online course, facilitators and teachers agreed that "parents should be logging into their student's online class and monitoring their student's progress." Caitlyn (F) argued that in online courses parents actually "need to be a more active partner in monitoring how their kids are doing" compared to face-to-face courses, because online students tend to have more flexibility in their learning pace. Samantha (F) shared that "teenagers aren't always looking ahead and paying attention to where they are...and could easily lose track and get [in] over their head."

At the start of the semester parents and students were provided with pacing guides that listed all of the course assignments that were also viewable in the gradebook. However, teachers and facilitators identified several obstacles that prevented many parents from regularly doing so. First, the grade book for the online courses was not integrated with the local school system's online gradebook, and some parents were "not 
willing to go and sign-on to two different [portals] just to see their student's grade." Second, there was not a parent portal with a student progress dashboard. Instead parents had to use students' login information to access the course and then navigate to the gradebook, which may prove difficult for some parents. Furthermore, facilitators experienced that some parents found it difficult to interpret students' progress and grades because of the self-paced nature of most of the online courses. As a result, Casey (F) recommended to parents that they tell their students, "Hey, pull up your online class, and can you show me where you're at." However, even when students showed parents the gradebook, parents relied somewhat on the student to interpret the scores, and students were not always truthful. Dana stated, "The parents believe them, which they probably shouldn't." Dana (F) believed that ideally parents would have access to a "parent portal" that would display students' progress in relation to the pacing guide so that parents could easily "see their progress and be able to say, 'What a minute. This says you should be here by October 21."'

Due to these obstacles, the interviewed teachers and facilitators commonly contacted parents to inform them of their students' grades-especially when students were underperforming. All teachers were required to provide parents with progress reports twice during the semester. The facilitators also regularly sent additional progress reports home to parents. Amanda (F), who sent home progress report emails every couple of weeks when students were behind, explained, "I send home more communication than a [face-toface] teacher would just so that no student, no parent can say they were not informed." Dana (F) similarly sent home progress reports "every Friday if they're getting below a C" so that parents would start "paying attention a little bit more." However, Kay (F) found the "system for emailing parents [to be] horrible" because if the counselors did not enter in the correct parent email at registration, facilitators had no way to enter it in themselves and had to send emails individually. Kay (F) found that she had to personally email many of her parents, which took "an entire day." However, even after all that effort she still thought to herself, "I wonder, 'Are you opening this?” As a result, Tanner (F) stated, "If they're in danger of failing we'll make calls home and try to get their parents involved that way."

\section{Motivating}

When parents became aware of students' underperformance, facilitators and teachers expected them to motivate their students to become more engaged in learning activities. Teachers found that parents' regular physical presence made them especially important "to help motivate or drive their son or daughter to be successful." At a minimum, teachers and facilitators believed that parents should set high expectations on "day one" of the semester and give students an "extra push" when they failed to meet those expectations. Daphnie (T) added that parents should be "constantly celebrating" their students' successes and work to establish "a celebratory atmosphere for successful students."

When expectations and encouragement proved insufficient, teachers and facilitators recommended that parents use rewards and punishments to motivate their students. Overall, facilitators and teachers were more aware of parent punishments than rewards. Punishments typically involved "grounding" or removing privileges such as "keys to their truck" or "their phone." Facilitators found that these types of punishments were "fantastic" and highly effective. Although facilitators could not use the same punishments as parents, Kay (F) found that with parent support she was able to add additional punishments. "I just had a parent who said, 'Can you please give my student a detention every day this week so that he stays after every day this week."' 


\section{Organizing and Managing}

Teachers and facilitators believed that parents should organize and manage students' learning activities at home and manage their learning schedule to ensure an on-time course completion. Kandice (T) explained that many students had to learn from home because in "some schools, the students are only in the computer lab one hour a week, which is not enough time." Samantha (F) required her students to attend a daily lab but still found that "it's hard for some kids to keep up" and they "have to do some work at home." Carl (F) added that even when students attended a daily lab, it could be difficult to perform some tasks because the lab was "not always that free of interruption."

Providing "a nice quiet place for students to work" at home was not enough, and teachers and facilitators explained that parents should also help to ensure students stay on task because "kids can be easily distracted" when working online. Luke (F) summarized "You can provide the best workspace in the world, but I think it's good from time to time to check in and see what kids are doing."

Facilitators and teachers also acknowledged that some parents were unable to provide students with the resources or stability they needed at home. Amanda (F) stated, 'You'd be surprised how many do not have the Internet or do not have a computer at home." Devon (T) added that some students only had "slow Internet" that was insufficient to efficiently complete learning activities from home. Lynda (F) added that at times students had to work "at the library, Grandma's house, an aunt's house" so they could "stick to that schedule."

\section{Instructing}

Teachers and facilitators believed that parents could potentially provide students with important content support. Sabrina (T) shared, "Inevitably, a student is going to be working on their computer at night, and have a question, and not understand, and they might ask their parent. Sometimes the parent can answer the question, and sometimes they can't." However, teachers and facilitators agreed that for most parents "their child has surpassed their knowledge level." Tanner (F) found only "a handful of parents that are highly educated and can sit down with a student and work on some of these online classes." Teachers and facilitators were not concerned that parents were unable to provide content support because "everything is very clear" in the course, and "instructors have been more than happy to work with kids one-on-one." Kandice (T) added "even if you're not great at math, you can sit down and help your kid try to get through the math assignment" when students require more immediate assistance. Rick (T) explained that even if parents cannot assist with content related questions, "It's extremely helpful that the parent help with the reading, writing, and grammar."

Although parental assistance on assignments was valued by teachers and facilitators, Angela (T) stressed that some parents were "almost hand holding the student through the entire course" instead of helping the student develop independent learning skills. Three facilitators also suspected that some parents were actually doing the work for their students. 


\section{Discussion and Implications}

Guided by the ACE framework (Borup et al., 2014), this research examined online teacher and on-site facilitator perceptions and experiences regarding parental engagement in a large supplemental online program. Previous research has largely focused on parental engagement in full-time programs where parents were tasked with facilitating students' online learning at home. While parental engagement is especially important in full-time programs (Liu et al., 2010), most online students enroll in only one or two online courses to supplement their face-to-face programs (Evergreen Education Group, 2017). Research in full-time programs can provide insights into parental engagement in supplemental programs, but the authors of the ACE framework explained, "Differing learner models will also place varying emphasis on parent engagement. For instance, some full-time online programs require students to work from home, placing a greater need for parental monitoring, organizing, and instructing”' (Borup et al., 2014, p. 23).

Similar to research in full-time programs, online teachers and on-site facilitators interviewed for this research agreed that the needed level of parental engagement was dependent on student attributes and background. Additionally, this research found that on-site facilitators were able to alleviate some of the burden that would otherwise have been placed on parents. In fact, 11 of the 12 facilitators who participated in this research meet with the large majority of their students daily in a lab setting. As a result, they believed that parents' responsibilities were similar to that of a face-to-face course. However, online teachers did not find daily lab attendance to be typical across all of their students and found parents needed to fulfill more of a facilitator role when their students were not regularly working with a facilitator at school. Because all of the facilitators in this research were highly engaged in their students' learning, additional research is needed to examine parental engagement in supplemental programs with less involved facilitators or no facilitators at all.

While some parents were overly engaged — even to the point of possibly doing some of their students' workin general parents were under engaged in their students' online learning. Online administrators, teachers, and facilitators should seek strategies that effectively increase the support students receive from their parents. In this research, online teachers and on-site facilitators identified several obstacles to full parental engagement including parents' being unaware that their students were taking an online course, parents' lack of understanding of the online learning model used in the program, and the use of an online gradebook that was separate from the gradebook used at the brick-and-mortar school. Online teachers and on-site facilitators also encountered obstacles when they attempted to support parents in their responsibilities. For instance, online teachers commonly lacked accurate contact information and relied on facilitators to relay messages to parents. While it was easier for on-site facilitators to obtain accurate parent contact information, they could not update contact information in the system and instead had to email progress reports to those parents individually, which could prove to be a tedious and time consuming process. We recommend that programs require accurate parental email addresses and phone numbers at the time of registration. We also recommend establishing permissions that would allow online teachers and on-site facilitators to update incorrect contact information.

Online programs should work to create tools that support parents in their monitoring efforts. In this research, parents had to log into the course using their student usernames and passwords and then navigate to the gradebook. Even if parents were able to access the gradebook, online teachers and on-site facilitators 
found that the self-paced nature of the courses made it difficult for parents to interpret their students' overall grades and recognize when students were not maintaining adequate pace in the courses. We recommend that online programs provide a parent portal with a dashboard that clearly communicates important student performance and progress information. While previous researchers have described or advocated for similar dashboards for teachers (Borup, Graham, \&Drysdale, 2014; Adams Becker, Freeman, Giesinger Hall, Cummins, \&Yuhnke, 2016; Dickson, 2005; Rice \& Carter, 2016; Zhang \& Almeroth, 2010) and students (Patrick, Kennedy, \& Powell, 2013), additional attention needs to be paid to parent dashboards. While teacher dashboards are becoming more common, they can be ignored when poorly designed (Murphy et al., 2014). As a result, when designing parent portals and dashboards, designers should work closely with parents to ensure that they are designed in a way that will prove helpful for the intended stakeholders.

More difficult than providing tools and resources to parents are efforts to ensure parents actually fulfill their responsibilities. Hoover-Dempsey et al. (2005) explained that parents' engagement in their students' learning is dependent on how they perceive their own roles and responsibilities. They added that parents construct their roles socially through "experiences over time with individuals and groups related to schooling. These often include the parents' personal experiences with schooling, prior experience with involvement, and ongoing experiences with others related to the child's schooling (e.g., teachers, other parents)" (Hoover-Dempsey et al., 2005, p. 108). For face-to-face courses, parents have a wealth of experiences and models that have helped them envision what their engagement should be. In contrast, parents' experiences with online learning is limited-both as parents and students-and may lack models and opportunities to construct their roles for engaging in their students' online learning. Hoover-Dempsey et al. (2005) explained that "because it is socially constructed, parents' role construction for involvement is subject to change" (p. 108). As a result, online programs should thoughtfully provide parents with materials and supports that will help them overcome misconceptions and gain the understanding they need to effectively engage in their students' online learning.

Hoover-Dempsey and Sandler (1995, 2005) added that parents' decisions to engage in their students learning can be influenced by specific invitations. Surprisingly, online teachers in this research found that some parents were unaware that their students were even enrolled in an online course. Interviewed on-site facilitators commonly sent home a packet of orientation materials, and some even required parents to sign and return a form acknowledging they had read the packet. However, facilitators believed that the amount of information was overwhelming and ignored by many parents. As a result, some facilitators wished they could have a face-to-face orientation event with parents. Similar synchronous online events may reach additional parents who require additional flexibility. While a face-to-face or synchronous online event at the start of the semester may prove helpful for parents, programs should also explore ways that parents can also be invited to engage in their students' learning throughout the semester.

Lastly, Hoover-Dempsey and Sandler $(1995,2005)$ explained that outside demands on parents' time can prevent them from engaging in their students' learning even when they understand their responsibilities and are motivated to fulfill them. As a result, providing a regular place and time to learn with an engaged facilitator is especially important for student populations where parental engagement has been persistently low, including students whose parents have limited formal education (Al-Matalka, 2014) and/ or who have 
lower socioeconomic status (SES) (Alghazo \& Alghazo, 2015). Furthermore, facilitators in this research found that students struggled to complete work at home when they had no or slow Internet access. Rose, Smith, J ohnson, and Glick (2015) stated that while online learning can "be a critical tool in our search for equitable education across all aspects of our public education system...without proper planning, virtual schools could perpetuate or even exacerbate disparities in our system" (p. 71-72). School administrators should carefully consider each student's needs when deciding the types of supports required to create a successful online environment. When high parental engagement is unlikely, we recommend providing students with a time and place where their learning can be regularly supported by an engaged facilitator.

\section{Conclusion}

As online course enrollments grow, it is important to better understand how parents can help their students be successful in online courses. Previous research has focused on parental engagement in full-time online programs where students learn primarily at home. However, parental engagement is likely different in supplemental online programs - especially when students are provided with an on-site facilitator. Our analysis of interviews with online teachers and on-site facilitators found that the level of parental engagement required could be reduced by a highly engaged facilitator. However, even with a highly engaged facilitator, parents had important responsibilities in their students' effective online learning. Participants in this research found that parents commonly had misconceptions regarding their responsibilities and in some cases were unaware that their students were even enrolled in an online course. Online programs should work with parents before and after registration to ensure that they understand and are willing to fulfill their responsibilities. The lack of parent resources and online portal also made it difficult for parents to fulfill their responsibilities.

The findings from this research should be understood within the context it was conducted. While not generalizable, the findings from this research may prove insightful to others seeking to understand and improve parental engagement in other online programs. Building on this research, others should seek to conduct more generalizable research. Future researchers should also collect data directly from parents to better understand their perceptions and the obstacles they encounter when attempting to engage in their students learning. While obtaining parental research participation has proven difficult in supplemental online programs (Oviatt, Graham, Borup, \& Davies, 2018), parents can provide unique insights into strategies that may help improve learning outcomes.

\section{Acknowledgement}

This research was supported by Michigan Virtual through a Fellowship with its Michigan Virtual Learning Research Institute. 


\section{References}

Adams Becker, S., Freeman, A., Giesinger Hall, C., Cummins, M., \&Yuhnke, B. (2016). NMC/ CoSN Horizon Report: 2016 K-12 Edition. Austin, TX: The New Media Consortium. Retrieved from http:// odn.nmc.org/ media/ 2016-nmc-cosn-horizon-report-k12-EN.pdf

Alghazo, Y., \&Alghazo, R. (2015). The effect of parental involvement and socioeconomic status and elementary students' mathematics achievement. J ournal of Social Sciences and Humanities, 1(5), 521- 527. doi: 10.3389/ fpsyg.2018.00952

Al-Matalka, F. I. M. (2014). The influence of parental socioeconomic status on their involvement at home. International J ournal of Humanities and Social Science, 4(5), 146- 154. Retrieved from http:// www.ijhssnet.com/view.php?u=http:// www.ijhssnet.com/journals/Vol 4 No_5_March 2014/15.pdf

Borup, J . (2016). Teacher perceptions of parental engagement at a cyber high school. J ournal of Research on Technology in Education, 48, 67-83. doi: 10.1080/ 15391523.2016.1146560

Borup, J . (2018). On-site and online facilitators: Current and future direction for research. In K. Kennedy \&R. Ferdig (Eds.), Handbook of research on K-12 online and blended learning (2nd ed.; pp. 423442). ETC Press. Doi:10.1184/ R1/6686813

Borup, J ., Graham, C. R., \&Davies, R. S. (2013). The nature of parental interaction in a virtual high school setting. American J ournal of Distance Education, 27, 40-55. doi: 10.1080/08923647.2013.754271

Borup, J., Graham, C. R., \&Drysdale, J . (2014). The nature of online teacher engagement at an online high school. British J ournal of Educational Technology, 45, 793-806. doi: 10.1111/ bjet.12089

Borup, J ., Stevens, M., \& Hasler Waters, L. (2015). Student and parent perceptions of parental engagement at an online charter high school. Online Learning, 19(5). Retrieved from https:// olj.onlinelearningconsortium.org/index.php/olj/article/view/699

Borup, J . \& Stimson, R. (2019). Online teachers' and on-site facilitators' shared responsibilities at a supplemental virtual secondary school. American J ournal of Distance Education, 33(1). doi: 10.1080/08923647.2019.1554984

Borup, J ., West, R. E., Graham, C. R., \&Davies, R. (2014). The adolescent community of engagement framework: A lens for research on K-12 online learning. J ournal of Technology and Teacher Education, 22, 107-129. Retrieved from https:// www.learntechlib.org/primary/p/112371/

Black, E. W. (2009). An evaluation of familial involvements' influence on student achievement in K-12 virtual schooling. University of Florida, Gainesville, FL. https:// doi.org/ 3367406 
Cavanaugh, C., Barbour, M., Brown, R., Diamond, D., Lowes, S., Powell, A., ... Van der Molen, J . (2009). Research committee issues brief: Examining communication and interaction in online teaching. Vienna, VA: iNACOL. Retrieved from http:// www.inacol.org/ research/docs/NACOL_QualityTeaching-lr.pdf

Dickson, W. P. (2005). Toward a deeper understanding of student performance in virtual high school courses: Using quantitative analyses and data visualization to inform decision making. Naperville, IL: NCREL/Learning Point Associates. Retrieved from http:// www.mivu.org/LinkClick.aspx?fileticket=I5uq2DZ7Y\%2BI\%3D\&tabid=373

Epstein, J . L. (1995). School/family/ community partnerships. Phi Delta Kappen, 76(9). https:// doi.org/ 10.2307/ 2967352

Evergreen Educational Group. (2017). Keeping pace with K-12 onlinelearning 2016. Evergreen Education Group. Retrieved from http:// www.kpk12.com/wp-content/uploads/EEG KP2016web.pdf

Freidhoff, J . R. (2017). Michigan 's K-12 virtual learning effectiveness report 2015-16. Lansing, MI: Michigan Virtual University. Retrieved from http://media.mivu.org/institute/pdf/er_2016.pdf

Glaser, B. G. (1965). The constant comparative method of qualitative analysis. Social Problems, 12(4), 436- 445. Retrieved from http:// www.jstor.org/ stable/ 798843

Hasler Waters, L. (2012). Exploring the experiences of learning coaches in a cyber charter school: A qualitative case study (Doctoral dissertation, University of Hawaii at Manoa, Honolulu). Retrieved from https:// scholarspace.manoa.hawaii.edu/handle/ 10125/100883

Hasler Waters, L., \&Leong, P. (2014). Who is teaching? New roles for teachers and parents in cyber charter schools. J ournal of Technology and Teacher Education, 22(1), 33- 56. Retrieved from https:// www.learntechlib.org/primary/p/112373/

Hoover-Dempsey, K. V., \& Sandler, H. M. (1995). Parental involvement in children's education: Why does it make a difference? Teachers College Record, 97(2), 311- 331. Retrieved from https:// www.tcrecord.org/ Issue.asp? volyear=1995\&number=2\&volume=97

Hoover-Dempsey, K. V., \& Sandler, H. M. (2005). Final performance report for OERI Grant \# R305T010673: The social context of parental involvement: A path to enhanced achievement. Washington, D.C. Retrieved from http:// www.vanderbilt.edu/ peabody/familyschool/Reports.html

Hoover-Dempsey, K. V, Walker, J . M. T., Sandler, H. M., Whetsel, D., Green, C. L., Wilkins, A. S., \& Closson, K. (2005). Why do parents become involved? Research findings and implications. The elementary school journal, 106(2), 105- 130. doi: 10.1086/ 499194 
Larkin, I. M., Brantley-Dias, L., \&Lokey-Vega, A. (2015). J ob satisfaction, organizational commitment, and turnover intention of online teachers in the K-12 setting. Online Learning, 20(3), 26- 52. Retrieved from https:// olj.onlinelearningconsortium.org/ index.php/olj/article/ view/ 986

Litke, D. (1998). Virtual schooling at the middle grades: A case study résumé. The J ournal of Distance Education, 13(2), 33-50. Retrieved from http:// www.ijede.ca/ index.php/jde/ article/ view/ 145/ 386

Liu, F., Black, E., Algina, J ., Cavanaugh, C., \& Dawson, K. (2010). The validation of one parental involvement measurement in virtual schooling. J ournal of Interactive Online Learning, 9(2), 105- 132. Retrieved from https:// www.learntechlib.org/p/ 109414/

McNeal, R. B. (2012). Checking in or checking out? Investigating the parent involvement reactive hypothesis. J ournal of Educational Research, 105(2), 79- 89. doi: $\underline{10.1080 / 00220671.2010 .519410}$

Michigan Public Act No. 60. (2013). Retrieved from http:// www.legislature.mi.gov/ docu- ments/20132014/publicact/htm/2013-PA-0060.htm

Michigan Virtual. (2017). Parent guide to online learning (5th ed.). Retrieved from https:// mvlri.org/wpcontent/uploads/2017/03/parentguide_508.pdf

Murphy, R., Snow, E., Mislevy, J ., Gallagher, L., Krumm, A., \& Wei, X. (2014). Blended learning report. Michael \& Susan Dell Foundation. Retrieved from https:// 1k8hc03ylh05464h1122sxwbwpengine.netdna-ssl.com/ wp-content/ uploads/2016/01/MSDF-Blended-Learning-Report-May2014.pdf

Oviatt, D. R., Graham, C. R., Borup, J ., \& Davies, R. S. (2018). Online student use of a proximate community of engagement in an independent study program. Online Learning, 22(1), 223- 251. doi: $10.24059 /$ olj.v22i1.1153

Patrick, S., Kennedy, K., \& Powell, A. (2013). Mean what you say: Defining and integrating personalized, blended, and competency education. International Association for K-12 Online Learning. Retrieved from http:// www.inacol.org/ wp-content/ uploads/2015/ 02/ mean-what-yousay.pdf

Rice, M. F., \& Carter, R. A. (2016). Online teacher work to support self-regulation of learning in students with disabilities at a fully online state virtual school. Online Learning, 20(4), 118-135. Retrieved from https:// olj.onlinelearningconsortium.org/index.php/olj/article/ view/ 1054

Roblyer, M. D., Freeman, J ., Stabler, M., \& Schneidmiler, J . (2007). External evaluation of the Alabama ACCESS initiative phase 3 report. Eugene, OR: International Society for Technology in Education. Retrieved from http:// accessdl.state.al.us/2006Evaluation.pdf 
Rose, R. M., Smith, A., J ohnson, K., \& Glick, D. (2015). Ensuring equitable access in online and blended learning. In T. Clark \& M. K. Barbour (Eds.), Online, blended, and distance education in schools: Building successful programs (pp. 71- 83). Sterling, VA: Stylus Publishing.

Wilder, S. (2014). Effects of parental involvement on academic achievement: A meta-synthesis. Educational Review, 66(3), 377- 397. https:// doi.org/ 10.1080/00131911.2013.780009

Wolcott, H. F. (1994). Transformative qualitative data: Description, analysis, and interpretation. Thousand Oaks, CA: Sage Publications.

Zhang, H., \&Almeroth, K. (2010). Moodog: Tracking student activity in online course management systems. J ournal of Interactive Learning Research, 21(3), 407-429. Retrieved from https:// www.learntechlib.org/primary/p/32307/

\section{Athabasca} University

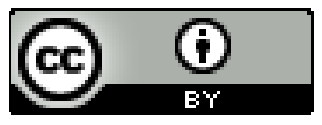

